Jurnal Riset Biologi dan Aplikasinya, Volume 2, Nomor 2, September 2020

Jurnal Riset Biologi dan Aplikasinya

\title{
Addition of Carbon Sources to Pineapple Waste Media in the Production of Single Cell Protein Biomass Saccharomyces cerevisiae
}

\section{Penambahan Sumber Karbon Pada Media Limbah Nanas dalam Pembuatan Protein Sel Tunggal Biomassa Saccharomyces cerevisiae}

\author{
Anggi Nurmalasari*, Shinta Maharani \\ Agroindustry Engineering, Faculty of Technology and Vocational Skills Education, \\ Universitas Pendidikan Indonesia
}

\section{Article History \\ Received : 10 September 2020 Approved : 25 September 2020 Published : 30 September 2020}

Keywords: Fermentation; pineapple peel; single cell protein; saccharomyces cerevisiae

Kata Kunci: Fermentasi; Kulit nanas; protein sel tunggal; saccharomyces cerevisiae

\begin{abstract}
Single-cell protein (SCP) is the term used for crude or pure protein derived from simple single or multi-celled microorganisms. Pineapple peel contains monosaccharides as much as $10.8 \%$ so that it can be used as a fermentation medium in single-cell protein production. The purpose of this study was to determine the effect of adding carbon sources of fructose and sucrose on $\mathrm{pH}$, cell dry weight, and protein content in the manufacture of single-cell proteins. This study used a completely randomized design (CRD) with two factors, namely the addition of carbon (fructose, sucrose, and control) and fermentation time (24.48, and 72 hours). The data analysis used the variance test and the Duncan Multiple Range Test (DMRT) continued to test with a confidence level of 95\%. The results showed that the addition of carbon to the media had a very significant effect on media $\mathrm{pH}$, cell dry weight, and protein content. In the medium with the addition of fructose it has a $\mathrm{pH}$ of 3.81 ; dry weight 0.4203 grams; and protein content $69.08 / \mathrm{L}$. Whereas in the media with the addition of sucrose, the $\mathrm{pH}$ was 4.33 , the dry weight of the cells was 0.3385 grams, and the cells had a protein content of $85.55 \mathrm{mg} / \mathrm{L}$. The addition of a fructose carbon source gave the cell dry weight more than the addition of carbon sucrose
\end{abstract}

\begin{abstract}
Abstrak
Protein sel tunggal (PST) adalah istilah yang digunakan untuk protein kasar atau murni yang berasal dari mikroorganisme bersel satu atau banyak yang sederhana. Kulit buah nanas mengandung monosakarida sebanyak 10,8\% sehingga dapat dimanfaatkan sebagai media fermentasi pada produksi protein sel tunggal. Tujuan penelitian ini adalah untuk menguji pengaruh penambahan sumber karbon fruktosa dan sukrosa terhadap pH, berat kering sel, dan kadar protein dalam pembuatan protein sel tunggal. Penelitian ini menggunakan Rancangan Acak Lengkap (RAL) dua faktor yaitu penambahan karbon (fruktosa, sukrosa, dan kontrol) dan waktu fermentasi (24,48, dan 72 jam). Analisis data menggunakan uji sidik ragam dan uji lanjut Duncan Multiple Range Test (DMRT) dengan taraf kepercayaan 95\%. Hasil penelitian menunjukkan bahwa penambahan karbon pada media memberikan pengaruh yang sangat nyata terhadap $p H$ media, berat kering sel dan kadar protein. Media dengan penambahan fruktosa memiliki pH sebesar 3,81; berat kering 0,4203 gram; dan kadar protein 69,08/L. Pada media dengan penambahan sukrosa menghasilkan pH sebesar 4,33 dengan berat kering sel sebanyak 0,3385 gram, dan sel memiliki kadar protein sebesar $85,55 \mathrm{mg} / \mathrm{L}$. Penambahan sumber karbon fruktosa memberikan berat kering sel lebih banyak dibandingkan dengan penambahan karbon sukrosa.
\end{abstract}

How to cite: Nurmalasari, A \& Maharani, S. (2020). Addition of Carbon Sources to Pineapple Waste Media in the Production of Single Cell Protein Biomass Saccharomyces cerevisiae. Jurnal Riset Biologi dan Aplikasinya, 2(2), $70-76$. 


\section{INTRODUCTION}

The increasing population of humans and animals causes the demand for food and animal feed to increase. Food and animal feed must contain good nutritional elements such as protein. A large number of protein needs for humans and animals results in proteins derived from animals and plants that are not sufficient for human and animal populations. Since the 1950 s, efforts have been made to find alternative sources of protein. Among them are single-cell proteins derived from microorganisms. Proteins obtained from microorganisms are cheap and compete with other protein sources and can provide good nutritional value depending on the amino acid composition (Dhanasekaran et al., 2011).

Single-cell protein is a term used for crude or pure protein derived from unicellular or multicellular microorganisms, such as bacteria, yeast (yeast), fungi, algae, and protozoa. The microorganism used in this study was S.cerevisiae yeast. When compared to the production of protein from animals and plants, single-cell protein production is more efficient, because it does not require a large area, does not cause waste, and the production process is fast, reproduction of microorganisms such as bacteria and yeast can give greater yields every hour, while algae take less than one day (Pawignya, 2011).

Single-cell proteins can be produced on several different substrates. Conventional substrates such as starch, molasses, fruit, and vegetable waste have been used for the manufacture of single-cell proteins (Suman et al., 2015; Srividya et al., 2014). Monosaccharide and disaccharide substrates are mostly used for the manufacture of single-cell proteins because monosaccharides and disaccharides are natural microbial substrates and are renewable raw materials.

Pineapple fruit is widely used by most Indonesians for consumption needs. Apart from being consumed fresh, pineapples are also widely used as raw material for the agricultural industry with various products such as processed pineapples, such as jam, sweets, syrup, lunkhead, chips, canned fruit, which are Indonesia's leading export products (Nastiti et al., 2013). From the various types of processing, pineapple waste will be obtained in large enough quantities. Pineapple waste consists of peel waste and pineapple stem waste. Waste or by products of pineapple are still limited in use and relatively just thrown away (Tahir et al., 2008).
The nutritional content of pineapple peels includes water $84.50 \%$, reducing sugar $6.62 \%$, protein $6.4 \%$, and crude fiber $16.7 \%$ (Nastiti et al., 2013). The sugar content in pineapple peel can be used in making single-cell protein. Because microorganisms will use this sugar as a carbon source and as an energy source. Carbon sources that can be added to the manufacture of single-cell proteins are monosaccharides and disaccharides (Pawignya, 2011). Meanwhile, Purwitasari et al. (2004) in her study stated that the carbon source added to the manufacture of single-cell proteins comes from coconut water which contains glucose, sucrose, fructose, inositol, and sorbitol. Then, the research of Pawignya (2011) and Masithoh (2012) used sucrose as a carbon source in a single cell protein maker. Therefore this study aims to determine the effect of adding types of carbon sources on $\mathrm{pH}$, cell dry weight, and protein content in the manufacture of single-cell proteins. The carbon sources added in this study were fructose and sucrose. Fructose is one of the monosaccharide carbohydrates, while sucrose is one of the disaccharide carbohydrates.

\section{MATERIALS AND METHODS}

This research was conducted at the Quality Control Laboratory, Agricultural Product Processing Technology Laboratory and Instrument Laboratory Department of Teknologi Agroindustri, FPTK Universitas Pendidikan Indonesia Bandung.

This research was conducted using two-factor completely randomized design (CRD) experiments, namely the type of carbon source and fermentation time. The carbon source factor consists of three treatments, namely no addition of carbon, the addition of fructose, and the addition of sucrose. While, the fermentation time factor consisted of three fermentation time treatments, namely 24 hours, 48 hours, and 72 hours.

The tools used in the manufacture of this single-cell protein are autoclave, shaking incubator, $250 \mathrm{ml}$ Erlenmeyer, spirit burner, laminar air flow cabinet, screw tube, loop needle, micropipette. Meanwhile, the tools used for single-cell protein analysis are $\mathrm{pH}$ meter, centrifuge, analytical balance, oven, desiccator, UV-VIS spectrophotometer, and cuvette.

The materials used in the manufacture of this single-cell protein are pineapple peel waste, as a source of $S$. cerevisiae, sucrose, fructose, PDA media, aquadest, $\left(\mathrm{NH}_{2}\right)_{2} \mathrm{SO}_{4}, \quad \mathrm{KH}_{2} \mathrm{PO}_{4}, \mathrm{MgSO}_{4}, \mathrm{CaCl}_{2}$, $\mathrm{CH}_{3} \mathrm{COOH},\left(\mathrm{CuSO}_{4} .5 \mathrm{H}_{2} \mathrm{O}\right.$ and $\left.\mathrm{KNaC}_{4} \mathrm{H}_{4} \mathrm{O}_{6}\right)$. While, 
the materials used for the single-cell protein analysis test are Bovine Serum Albumin (BSA) Standard Solution (1;2; 3; 4; $5 \mathrm{mg} / \mathrm{L})$, Biuret Solution $\left(\mathrm{CuSO}_{4} .5 \mathrm{H}_{2} \mathrm{O}\right.$ and $\left.\mathrm{KNaC}_{4} \mathrm{H}_{4} \mathrm{O}_{6}\right)$, and $30 \%$ $\mathrm{NaOH}$ solution.

The stages of making single-cell protein include isolation of $S$. cerevisiae, making media for pineapple peel, making a starter, and the fermentation process.

\section{S. cerevisiae Isolation}

Instant dry yeast containing $S$. cerevisiae with an additional $9 \mathrm{ml}$ of sterile distilled water, then was diluted up to $10^{-6}$. To get a single colony, dilution was carried out so that the growth of $S$. cerevisiae is not too dense. The inoculum at $10^{-1}$ dilution to $10^{-6}$ dilution was cultured on PDA medium using the slant method, then two inoculums were evenly scratched on the surface, then incubated at $30^{\circ} \mathrm{C}$ for 48 hours (Febriyanti et al., 2017). Colony morphology of growing $S$. cerevisiae is identified macroscopically from the colony form such as pearl grains along the inoculation line, smooth surface texture, and yellowish-white color (Septriani, 2009).

\section{Pineapple Peel Wasted Medium Preparation}

500 grams of pineapple peel waste was washed, then blended with $500 \mathrm{ml}$ aquadest for 2 minutes with a blender speed of $21,000 \mathrm{rpm}$. The pineapple solution is filtered using a filter cloth. Pineapple filtrate is taken and pasteurized at $61^{\circ} \mathrm{C}$ for 30 minutes and then cooled (Pawignya, 2011). This solution is referred to as a fermentation medium.

3. Preparation of S. cerevisiae Starter Solution

The starter solution contains purified $S$. cerevisiae. In making this starter, there are three treatments for adding carbon sources, namely: without adding a carbon source (control) and adding a carbon source in the form of fructose and a carbon source in the form of sucrose. The starter can be made on a source of 20 grams of fructose or sucrose carbon dissolved in $100 \mathrm{ml}$ of aquadest, the $\mathrm{pH}$ of the solution is adjusted to 5 by adding $1 \mathrm{~N}$ $\mathrm{CH}_{3} \mathrm{COOH}$ solution, then adding 0.1 gram of nutrients $\left(\mathrm{NH}_{2}\right)_{2} \mathrm{SO}_{4}, \quad 0.1$ gram of $\mathrm{K}_{2} \mathrm{HPO}_{4}, 0,05$ grams of $\mathrm{MgSO}_{4}, 0.01$ grams of $\mathrm{NaCl}$, and 0.01 grams of $\mathrm{CaCl}_{2}$ (Mondal et al., 2012)). After that, the solution was sterilized at $121^{\circ} \mathrm{C}$ for 15 minutes. After a solution temperature of $\pm 29^{\circ} \mathrm{C}$, the pure culture of $S$. cerevisiae that had been isolated was inserted in two ose needle colonies into the solution then fermented using a shaking incubator for 2 days at $30^{\circ} \mathrm{C}$ (Pawignya, 2011).
4. Fermentation Process

$135 \mathrm{ml}$ of pineapple peel solution was added to the Erlenmeyer, after that the $\mathrm{pH}$ of the solution was adjusted to 4.5 with the addition of $1 \mathrm{~N}$ $\mathrm{CH}_{3} \mathrm{COOH}$ solution and then sterilized at $121^{\circ} \mathrm{C}$ for 15 minutes. After the solution temperature was \pm $29^{\circ} \mathrm{C}$, the solution was added with $15 \mathrm{ml}$ of starter and fermented for 24 hours, 48 hours, and 72 hours (Pawignya, 2011).

5. Test Method

a. Media pH Measurement (SNI-06-6989)

Measurement of the $\mathrm{pH}$ of the control media, fructose media, and sucrose media were carried out at 24,48 , and 72 hours using a $\mathrm{pH}$ meter that had been sterilized using a disinfectant.

b. Measurement of cell dry weight (Purwitasari, 2004)

$50 \mathrm{ml}$ of media samples centrifuged at 3000 rpm for 10 minutes. The precipitate is taken and transferred into a cup, then dried at $60^{\circ} \mathrm{C}$ for 5 hours. After drying, the cells are extracted by scraping them, then the resulting powder is weighed by the dry weight of the cells and analyzed for protein content.

c. Biuret method analysis of protein content (AOAC, 1995)

Protein content was measured by the biuret method using a UV-VIS spectrophotometer with a wavelength of $550 \mathrm{~nm}$.

This experiment was conducted by repeating the treatment twice and repeating the test analysis three times. The test analysis was carried out on single-cell proteins, namely $\mathrm{pH}$, cell dry weight, and protein content. Data analysis was carried out using the test of variance at the $95 \%$ confidence level, for treatments that were significantly different, further tested the Duncan Multiple Range Test (DMRT) with a confidence level of $95 \%$.

\section{RESULTS AND DISCUSSION}

Single-cell protein is a product of dry cell or microorganism biomass that can be used as a source of protein for food and feed (Babazadeh et al., 2014). In this study, the microorganism used was $S$. cerevisiae. S. cerevisiae contains lots of vitamins, especially vitamin B complex and minerals, so it is very good to be consumed as a dietary supplement for humans and animals. Also, the percentage of $S$. cerevisiae protein content was $45 \%$ higher than soy protein by $35 \%$ (Masithoh \& Nim, 2012).

The manufacture of single-cell protein in this study was carried out by adding a carbon source to the starter. The results of $\mathrm{pH}$ testing for each 
treatment and fermentation time can be seen in Table 1.

Changes in $\mathrm{pH}$ during fermentation of 23,48 , and 72 hours were still in the range of $S$. cerevisiae growth, namely at $3.72-4.71$, so that they did not inhibit the growth of $S$. cerevisiae. According to Pawignya (2011) stated that the $\mathrm{pH}$ of $S$. cerevisiae growth ranged from 3.5-5.5 with an incubation temperature of $25-30^{\circ} \mathrm{C}$. Before fermentation, the pineapple peel waste media in this study was set at $\mathrm{pH} 4.5$, because $S$. cerevisiae grew well at that $\mathrm{pH}$. During the fermentation time of 24,48 , and 72 hours, the media that was not added with a carbon source (control) had the highest $\mathrm{pH}$ of the media than the media with added fructose and sucrose. This is because the control media only uses the carbon source in the pineapple skin, namely glucose as much as 10.8\% (Dhanasekaran et al., 2011).

The addition of sucrose and fructose greatly affects the $\mathrm{pH}$ of the media, because this carbon is used by $S$. cerevisiae in the starter making, resulting in organic acids which lower the $\mathrm{pH}$. Sucrose is a disaccharide consisting of glucose and fructose. To hydrolyze disaccharides into monosaccharides, $S$. cerevisiae uses invertase enzymes (Azizah et al., 2012). This hydrolysis process causes the $\mathrm{pH}$ of the media with the addition of sucrose carbon to be higher than the addition of fructose carbon because $S$. cerevisiae needs to hydrolyze disaccharides for the fermentation process, whereas in the fructose medium $S$. cerevisiae does not need to hydrolyze it first. During fermentation, $S$. cerevisiae produces zymase and invertase enzymes, under an aerobic conditions the zymase enzyme will break down sucrose into monosaccharides (glucose and fructose) (Artiyani, 2011).

During fermentation of 0-24 hours, all media experienced a decrease in media $\mathrm{pH}$. This is because during fermentation of $S$. cerevisiae it produces organic acids such as malic acid, citric acid, acetic acid, tartaric acid, lactic acid, butyric acid, and propionic acid as a by-product (Masithoh \& Nim, 2012). S. cerevisiae has a generation time of 2 hours so that during 24 hours of fermentation, $S$. cerevisiae has undergone a process of cell addition and has entered a logarithmic growth phase (Artiyani, 2011 ). During 24 hours to 48 hours of fermentation, the $\mathrm{pH}$ decreased for each growth medium. The decrease in media $\mathrm{pH}$ from 24-48 hours is not as much as fermentation for 0-24 hours due to fermentation of 24-48 hours $S$. cerevisiae has entered a slow growth phase (Pratiwi, 2018). In this phase, the possibility of nutrients has decreased so that the $\mathrm{pH}$ decrease is not too much.

Tablel 1. Degree of medium acidity during fermentation

\begin{tabular}{cccc}
\hline Carbon & \multicolumn{3}{c}{$\mathrm{pH}$ time hour } \\
\cline { 2 - 4 } source & 24 & \multicolumn{3}{c}{48} \\
\hline Control & $4.34 \pm 0.04^{\mathrm{bc}}$ & $4.27 \pm 0.04^{\mathrm{b}}$ & $4.71 \pm 0.01^{\mathrm{c}}$ \\
Fructose & $3.83 \pm 0.16^{\mathrm{a}}$ & $3.72 \pm 0.02^{\mathrm{a}}$ & $3.81 \pm 0.01^{\mathrm{a}}$ \\
Sucrose & $4.22 \pm 0.07^{\mathrm{b}}$ & $4.11 \pm 0.00^{\mathrm{ab}}$ & $4.33 \pm 0.02^{\mathrm{bc}}$
\end{tabular}

Note: Different letter notations indicate a significant difference in the confidence level of the DMRT test of $95 \%$

Table 2. Cell dry weight $(\mathrm{g})$ fermentation result

\begin{tabular}{cccc}
\hline \multirow{2}{*}{$\begin{array}{c}\text { Carbon } \\
\text { source }\end{array}$} & \multicolumn{3}{c}{ Cell dry weight $(\mathrm{g})$ time hour } \\
\cline { 2 - 4 } & 24 & 48 & 72 \\
\hline Control & $0.2804 \pm 0.03^{\mathrm{b}}$ & $0.2168 \pm 0.01^{\mathrm{a}}$ & $0.2963 \pm 0.00^{\mathrm{c}}$ \\
Fructose & $0.3757 \pm 0.01^{\mathrm{cd}}$ & $0.4167 \pm 0.05^{\mathrm{d}}$ & $0.4203 \pm 0.01^{\mathrm{d}}$ \\
Sucrose & $0.3608 \pm 0.01^{\mathrm{c}}$ & $0.3712 \pm 0.02^{\mathrm{cd}}$ & $0.3385 \pm 0.03^{\mathrm{c}}$
\end{tabular}

Note: Different letter notations indicate a significant difference in the confidence level of the DMRT test of $95 \%$ 
Fermentation at 72 hours has increased $\mathrm{pH}$. This is because the food and nutrients of S.cerevisiae are starting to run low so that they undergo a change in protein in the medium for its metabolic activity. This metabolic process causes the formation of metabolites resulting from protein degradation such as urea and ammonium ions which cause an increase in pH (Purwitasari et al., 2004). Research conducted by Purwitasari (2004) regarding the manufacture of single-cell proteins from coconut waste medium shows that the longer fermentation time of the $\mathrm{pH}$ medium increases. Also, research conducted by Hasibuan (2019) also stated that during fermentation of $\mathrm{O}-24$ hours the $\mathrm{pH}$ of the media has decreased, while during 48-72 the $\mathrm{pH}$ of the media has increased.

Cell dry weight is a method of calculating cells by separating the substrate and cells formed from the fermentation process. The separation process uses a centrifugation technique and the residue that settles is dried at a temperature of $60^{\circ} \mathrm{C}$ for 5 hours. The results of the cell dry weight test for each treatment and fermentation time can be seen in Table 2 .

Based on Table 2, there is no specific trend from the results of the analysis of the dry weight of cells to the fermentation time. This occurs because the dry weight of impure cells comes from the cells resulting from the fermentation process. Several impurities are weighted as dry weight of cells, namely pineapple juice fibers which are filtered during filtering.

The increase in dry cell weight is strongly influenced by the rate of growth and the ability of cells to utilize nutrient sources in the media. The more nutrients S.cerevisiae needed for growth, the resulting increase in the number of cells during the incubation time (Masithoh \& Nim, 2012). The incubation time did not give significantly different results, but the longer the incubation time, the dry weight of the cells increased but not too much. Apart from the rate of growth, the dry weight of cells is very much influenced by oxygen. Oxygen and aeration are very important for the growth of $S$. cerevisiae because oxygen is quickly absorbed by $S$. cerevisiae and used to synthesize unsaturated fatty acids and sterols that form cell membranes, oxygen also stimulates the synthesis of molecules needed by $S$. cerevisiae to carry out metabolism and take up sugar. disaccharides. Aeration also has a very important role, according to Casselman (2005), continuous agitation/aeration can result in an increase in the number of yeast cells 10 to 15 times. This is evidenced by research conducted by Casselman (2005) that agitation with stable and sustainable stirring increases the number of yeast cells compared to the method of stirring. The unstable stirring factor also causes the cell growth process to have no specific tendency for each treatment.

Based on the analysis of completely randomized design data for cell dry weight, the addition of a carbon source has a very significant effect on cell dry weight. The fermentation time does not affect the dry weight of the cells. Based on the DMRT analysis, it is known that the fermentation time of S.cerevisiae on fructose and sucrose media was not significantly different, while in the control medium the fermentation time at 48 hours showed a significant difference in dry weight with fermentation time at 24 and 72 hours. In addition, the addition of carbon fructose and sucrose in the fermentation medium was significantly different from the control media, this is because the controlled media only used glucose contained in pineapple peels. The optimum dry weight of cells in the fermentation medium with the addition of fructose was 0.4203 grams, while the lowest cell dry weight in the controlled media was 0.2168 grams. This is similar to research conducted by Masithoh (2012), which shows that the addition of sucrose to single-cell protein-making from rice bran media produces more cell dry weight.

Analysis of protein content is one way to determine the absorption of nutrients during fermentation by S.cerevisiae cells. The results of testing protein levels in each treatment and fermentation time can be seen in Table 3 .

Table 3. Protein content $(\mathrm{mg} / \mathrm{L})$ fermentation results

\begin{tabular}{llll}
\hline Carbon & \multicolumn{3}{l}{ Protein content $(\mathrm{mg} / \mathrm{L})$ time hour } \\
\cline { 2 - 4 } Source & 24 & 48 & 72 \\
\hline Control & $89.81 \pm 15.18^{\mathrm{b}}$ & $73.03 \pm 10.96^{\mathrm{ab}}$ & $107.8 \pm 1.48^{\mathrm{c}}$ \\
Fructose & $85.05 \pm 9.10^{\mathrm{ab}}$ & $72.37 \pm 7.95^{\mathrm{a}}$ & $69.08 \pm 0.11^{\mathrm{a}}$ \\
Sucrose & $89.66 \pm 0.71^{\mathrm{b}}$ & $77.14 \pm 8.00^{\mathrm{ab}}$ & $85.55 \pm 0.82^{\mathrm{ab}}$ \\
\hline
\end{tabular}


Based on Table 3, the cell protein content of fructose media tends to decrease during the fermentation time. Meanwhile, the levels of cell protein from sucrose and control media increased. Meanwhile, research results conducted by Pawignya (2011) states that the longer the fermentation time produces more cell protein levels. The increase in protein levels can be caused by the increase in yeast cells which act as single-cell protein agents because $S$. cerevisiae consists of 50$52 \%$ crude protein, $30-37 \%$ carbohydrates, $4-5 \%$ fat, and $7-8 \%$ minerals. (Reed \& Nagodhawithana, 1988).

The single-cell protein content produced in the Purwitasari (2004) study was 26-38\%. The longer the fermentation takes, the less protein content in the Purwitasari (2004) study. Also, the protein content produced in Mashitoh's (2012) study regarding the manufacture of single-cell proteins from bran waste was 29-37\%. Meanwhile, research conducted by Hasibuan (2019) regarding the manufacture of single-cell proteins from rice water waste and pineapple waste is $0.02 \%$. Then, research conducted by Widanti (2012) regarding the manufacture of single-cell protein from tofu liquid waste has a protein cell content of $0.6 \%$. Meanwhile, the optimum protein content in this study was $0.01 \%$.

Based on the calculation of complete randomized design data analysis of protein content, the addition of carbon sources has a significant effect on cell protein levels. The fermentation time also affects the levels of cell protein significantly. DMRT further test analysis showed that the cell protein levels between the control media, fructose, and sucrose were not significantly different. However, the protein content of the 72-hour fermentation control medium was different from other media. The optimum protein content in the controlled media was $107.8 \mathrm{mg} / \mathrm{L}$, while the lowest protein content in the fructose medium was 69.08 $\mathrm{mg} / \mathrm{L}$. This is because the media with added carbon contains $30.8 \%$ sugar, this causes S.cerevisiae to experience osmotic pressure. According to Wardani et al. (2013) stated that fermentation in a medium containing $25 \%$ sugar is classified as fermentation under conditions of high osmotic pressure so that cells experience lysis due to hypertonic medium causing disrupted cell metabolism.

\section{CONCLUSION}

The addition of carbon fructose and sucrose to the starter of single cell protein production affected the $\mathrm{pH}$ of the fermentation medium and the dry weight of the cells. The addition of carbon has no effect on protein content. The carbon source in the form of fructose can increase the dry weight of the cells produced, while sucrose can increase the protein content of the resulting dry cells.

\section{REFERENCES}

AOAC. (1995). Official Methods of Analysis of The Association of Official Analytical Chemists. Washington DC: Association of Official Analytical Chemists. https://www.aoac.org/

Artiyani, A. (2011). Bioetanol dari Limbah Kulit Singkong Melalui Proses Hidrolisis dan Fermentasi dengan Saccharomyces cerevisiae. Prosiding Seminar Nasional Manajemen Teknologi http://eprints.itn.ac.id/2911/1/o1.

Azizah, N., Al-bAARI, A., \& Mulyani, S. (2012). Pengaruh Lama Fermentasi Terhadap Kadar Alkohol, pH, dan Produksi Gas pada Proses Fermentasi Bioetanol dari Whey dengan Substitusi Kulit Nanas. Jurnal Aplikasi Teknologi Pangan, 1(2), 72-77. http://jatp.ift.or.id/index.php/jatp/article/view/73.

Babazadeh, M., Soltani, M., Kamali, A., \& Asl, M. S. (2014). Production of single cell protein from Stickwater of kilka fish meal factory using Lactobacillus plantarum and Bacillus licheniformis. Iranian Scientific Fisheries Journal, 19(4): http://aquaticcommons.org/id/eprint/21797.

Casselman, R. (2004). Yeast Propagation and Maintenance : Principles and Practices by MB. : California: The maltose falcons. https://www.semanticscholar.org/paper/YeastPropagation-and-Maintenance-\%3A-Principles-andRaines

Casselman/e5e8ea0b5a6e5bcod41a3cec881e26a84doe4d6c

Dhanasekaran, D., Lawanya, S., \& Saha, S. (2011). Production of Single Cell Protein From Pineapple Waste. Innovative Romanian Food Biotechnology, 8, 26-32. https://www.researchgate.net/publication/235354886_Pr oduction_of_single_cell_protein_from_pineapple_waste_usi $n g$ yeast

Febriyanti, A. E., Sari, C. N., \& Adisyahputra, A. (2017). Efeltivitas Media Pertumbuhan Khamir Komersial (Saccharomyces Cerevisiae) Untuk Fermentasi Bioetanol Dari Eceng Gondok (Eichhornia crassipes). Bioma, 12(2), 112. https://doi.org/10.21009/bioma12(2).6

Masithoh, E., \& Nim, M. (2012). Pengaruh Konsentrasi Sukrosa Terhadap Pertumbuhan Khamir Roti Saccharomyces Cerevisiae Pada Media Bekatul Dalam Produksi Protein $\mathrm{Sel}$ Tunggal [Universitas Sebelas Maret].https://digilib.uns.ac.id/dokumen/detail/28307/ Pengaruh-Konsentrasi-Sukrosa-Terhadap-PertumbuhanKhamir-Roti-Saccharomyces-Cerevisiae-pada-MediaBekatul-dalam-Produksi-Protein-Sel-Tunggal.

Mondal, A.K., Sengupta, S., Bhowal, J., \& Bhattacharya, D.K. (2012). Utilization of Fruit Wastes in Producing Single Cell Protein. International Journal of Science, Environment and Technology, 1(5), 430-438. http://www.ijset.net/vol-5/1/IJSET\%209.pdf.

Nastiti, U. N., Lastuti, N. D. R., \& Nurhajati, T. (2013). The decreasing of crude fiber and the increasing of crude protein content of pineapple peel (Ananas comosus L. Merr) which fermented by cellulolytic bacteria (Actinobacillus sp. ML08). Agroveteriner, 1(2), 4654.http://journal.unair.ac.id/AGROVET@the 
decreasing-of-crude-fiber-and-the-increasing-of-crudeprotein-content-of-pineapple-peel-(ananas-comosus-l.merr)-which-article-6803-media-49-category-5.html.

Pawignya, H. (2011). Pembuatan Protein Sel Tunggal dari Limbah Nanas dengan Proses Fermentasi. Prosiding Seminar Nasional Teknik Kimia 'Kejuangan". Pengembangan Teknologi Kimia Untuk Pengolahan Sumber Daya Alam Indonesia, A05-1-A05-5. https://wrw.academia.edu/34661948/Pembuatan_Prote in_Sel_Tunggal_dari_Limbah_Nanas_dengan_Proses_F ermentasi.

Pratiwi, L. D. (2018). Kajian Kinetika Pertumbuhan Mikroorganisme Dan Kandungan B-Glukan Selama Fermentasi Tempe Dengan Penambahan Saccharomyces Cerevisiae. Lampung: Universitas Lampung. https://onesearch.id/Record/IOS4198.31796.

Purwitasari, E., Pangastuti, A., \& Setyaningsih, R. (2004). Pengaruh Media Tumbuh terhadap Kadar Protein Saccharomyces cerevisiae dalam Pembuatan Protein Sel Tunggal. Bioteknologi, 1(2), 37-42. https://doi.org/10.13057/biotek/c010202.

Purwanto, Maria G. M. (2014). Perbandingan Analisa Kadar Protein Terlarut dengan Berbagai Metode Spektroskopi UV-Visible. Jurnal Sains \& Teknologi, 7, 2: 64-71. http://repository.ubaya.ac.id/24502/2/Purwanto_Perban dingan\%20Analisa_2014.pdf.

Reed, G. \&' Nagodhawithana, T.W. (1988). Technology of yeast usage in winemaking. American Journal Enology Viticology, $\quad 39, \quad$ 83-85. https://wwrwajevonline.org/content/39/1/83.

Septriani, E. E. (2009). Isolasi dan Identifikasi Saccharomyces cerevisiae yang Diperoleh dari PG-PS Madukismo Yogyakarta yang Digunakan dalam Proses Fermentasi Alkohol [Yogyakarta]. https://repository.usd.ac.id/17106/2/058114148_Full.pd $f$.

Srividya, A.R., Vishnuvarthan, V.J., Murugappan, $M$ \& Dahake, P. G. (2014). International Journal for Pharmaceutical Research Scholars (IJPRS). International Journal for
Pharmaceutical Research Scholars (IJPRS), 2(I-4), 671677.

https://www.researchgate.net/publication/25969470 2_Single_cell_Protein-_A_Review.

Suman, G., Nupur, M., Anuradha, S., \& Pradeep, B. (2015). Single Cell Protein Production: A Review. International Journal of Current Microbiology and Applied Sciences, 4(9), 251-262. https://doi.org/10.1016/So 167-8760(01)00 179-9

Tahir, I., Sumarsih, S., \& Astuti, S. (2008). KAJIAN Penggunaan Limbah Buah Nenas Lokal (Ananas. Makalah Seminar Nasional Xviii, Jurusan Kimia FMIPA UGM. Https://Www.Academia.Edu/25998288/Kajian_Pen ggunaan_Limbah_Buah_Nenas_Lokal_Ananas_Como sus_L_Sebagai_Bahan_Baku_Pembuatan_Nata_Fruit _Waste_of_Local_Pineapple_Ananas_Comosus_L_as _Nata_Media

Wardani, A. K., Nurtyastuti, F., \& Pertiwi, E. (2013). Produksi Etanol Dari Tetes Tebu Oleh Saccharomyces Cerevisiae Pembentuk Flok (Nrrl-Y 265) Ethanol Production From Cane Molasses By Flocculant Saccharomyces Cerevisiae (Nrrl-Y 265). Agritech, 33(2), 131-139. https://doi.org/https://doi.org/10.22 146/agritech.9 810 .

Widanti, A. (2012). Produksi Protein Sel Tunggal Dari Limbah Cair Tahu Dengan Kultur Saccharomyces cerevisiae 3005. Yogyakarta: Universitas Islam Negeri Sunan Kalijaga. http://digilib.uin suka.ac.id/id/eprint/10791.

Wijaya, A. I. P. (2013). Kadar Protein dan Organoleptik pada Berbagai Macam Tempe dengan Variasu Bahan dari Koro Pedang (Canavalia ensiformis L. DC) dan Kedelai (Glycine $\max (\mathrm{L}$.) Merr). Salatiga: Universitas Kritsten Satya Wacana. https://repository.uksw.edu/bitstream/123456789/4 677/2/T1_652009016_Full\%20text.pdf. 